\title{
The Potency of Artocarpus Heterophyllus Leaf as a Facial Skin Care Ingredient in Clay Mask Formulation
}

\author{
Widyawati Tri ${ }^{1, *}$, Syarifah Siti ${ }^{1}$, Daulay Milahayati², Mustanti Lolyta Fitri ${ }^{3}$ \\ 1Department of Pharmacology and Therapeutic, Faculty of Medicine, Universitas Sumatera Utara, \\ Medan, Indonesia \\ ${ }^{2}$ Department of Physiology, Faculty of Medicine, Universitas Sumatera Utara, Medan, Indonesia \\ ${ }^{3}$ Faculty of Pharmacy, Universitas Sumatera Utara, Medan, Indonesia
}

\begin{abstract}
A B S T R A C T
Artocarpus heterophyllus (Ah), common name as nangka, has been reported to have antidiabetic, antihyperlipidemia, antimicrobial and antioxidant activity. Balinese women used its leaves for facial treatment. This study aims to evaluate its leaf potency for facial skin care. Ethanol extract of Ah (EEAh) that obtained by maceration was prepared into 3 clay mask formulations (FI: 1\%, FII:3\% and FIII:5\%). F0 was used as control group. A total of 12 volunteers were treated with clay mask to evaluate its effect on moisture and pores size after intervention. The data were analysed using Kruskall Wallis and Mann Whitney test. The results showed that skin moisture increased after intervention (FI:3.7\%; FII:4.7\%;FIII:7.3\%). Pores size decreased in FI (6.3\%) and FII (13.4\%). Statistically, there were significant different between F0-F1 ( $\mathrm{p}=0.043$ ), F0-F2 and F0-F3 ( $\mathrm{p}=0.046$ of each). The present study conclude that clay mask containing A. heterophyllus leaf ethanol extract have potency to be used as facial skin care.
\end{abstract}

Keywords: Artocarpus heterophyllus, clay mask, leaf, extract

A R T I C L E I N F 0: Received 19 Oct. 2019; $\quad$ Review Completed 10 dec 2019; $\quad$ Accepted 12 Dec. 2019; $\quad$ Available online 15 Dec. 2019

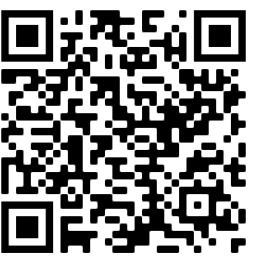

Cite this article as:

Widyawati Tri', Syarifah Siti, Daulay Milahayati, Mustanti Lolyta Fitri, The Potency of Artocarpus Heterophyllus Leaf as a Facial Skin Care Ingredient in Clay Mask Formulation, Asian Journal of Pharmaceutical Research and Development. 2019; 7(6):51-54 , DOI: http://dx.doi.org/10.22270/ajprd.v7i6.631

*Address for Correspondence:

Tri Widyawati, Department of Pharmacology and Therapeutic, Faculty of Medicine, Universitas Sumatera Utara, Medan, Indonesia

\section{INTRODUCTION}

$\mathrm{F}$ Tacial skin health is an important part to get more attention $^{1}$ as it is an important aspect of aesthetics ${ }^{2}$. Natural ingredients have been used traditionally for dermatologic disorder which over the last 20 years, clinical and laboratory studies have identified the benefit of natural ingredient for skin care ${ }^{3}$. Facial masks are common products utilized for skin rejuvenation. One of the most popular facial mask preparations is the wash-off type with a clay base, which is often called as clay facial masks ${ }^{2}$.

Artocarpus heterophyllus (A. heterophyllus), commonly known as the jackfruit tree or nangka in local name, is a plant that easy found in Indonesia. This plant originating from Southeast and South Asia ${ }^{4}$. Phytochemical studies have reported that this plant contains compounds that may have been responsible for their pharmacological activities like the sterol, prenylflavones, carotenoids, tocopherols and flavonoids ${ }^{7}$. Traditionally, many Balinese women in Indonesia use its leaves for facial treatments ${ }^{6}$. Siregar et al, $2018^{7}$. compared the antioxidant activity of the leaves and stems of this plant in a peel-off mask preparation which showed that the antioxidant activity of the stem parts was higher than the methanol extract leaf. Thus, based on the literature, studies of the clay masks containing ethanol extract of A. heterophyllus leaves as a skin care ingredient have not been reported yet.

\section{MATERIAL AND METHODS}

The study was conducted during April to September 2019 and has been approved by Health Research Ethical Committee, Faculty of Medicine, Universitas Sumatera Utara, Medan, Indonesia: No.652/TGL/KEPK FK USURSUP HAM/2019. 


\section{Materials}

The leaves were collected from Galang, Deli Serdang, Indonesia during. The plant was authenticated by Herbarium Medanense, FMIPA, Universitas Sumatera Utara.

The raw material was prepared by washing the leaves and dried under temperature room. The dried leaves then were grinded followed with maceration using ethanol $96 \%$ to obtain A. heterophyllus ethanol extract (EEAh). EEAh then were prepared into 3 concentration in clay mask formulations (F1:1\%; F2:3\%; F3:5\%). F0 contained a basic clay formulation was prepared as control.

\section{Methods}

After signing informed consent, a total of selected 12 female volunteers were divided into 4 groups. Each group were masked with:

F0 : basic clay formulation

F1 : basic clay formulation + EEAh $1 \%$

$\mathrm{F} 2$ : basic clay formulation + EEAh 3\%

$\mathrm{F} 3$ : basic clay formulation + EEAh 5\%
Skin test was conducted before mask application. The volunteers that have no irritation signs only were included to the study. Skin moistures and pores size were measured using skin analyser (Aroma, SG) before and after masking. Skin moistures was classified as: dehydration:0-29\%; normal:30-50\%; hydration:51-100\% while pores size was divided to: small: 0-19; large: 20-39 and very large:40-100.

Data were analysed with Kruskall Wallis and Mann Whitney test using IBM SPSS Statistic 22.

\section{RESULTS}

Effect of clay mask containing Artocarpus heterophyllus leaf ethanol extract on skin moisture

Table 1 showed the effect of clay mask containing EEAh on skin moisture. It showed that the skin moisture before and after treatment was in normal range (27-30\%). All extracts showed the ability to increase the moisture level as follows: F1 from $27.0 \pm 1.73 \%$ to $28.0 \pm 1.73 \%$; F2 from $28.3 \pm$ $0.57 \%$ to $29.7 \pm 0.57 \%$; while $\mathrm{F} 3$ from $27.7 \pm 0.57 \%$ to $29.7 \pm 0.57 \%$. Statistically, there were no significant different among groups and intra groups $(p>0.05)$. However, Mann Whitney test showed that the distribution between F0F1 different significantly ( $p=0.043$ two tailed).

Table 1. Effect of clay mask containing EEAh on skin moisture

\begin{tabular}{|l|l|l|l|}
\hline \multirow{2}{*}{ Group } & Moisture (\%) & After & \multirow{2}{*}{$\boldsymbol{P}^{\boldsymbol{a}}$} \\
\cline { 2 - 4 } & Before & $30.7 \pm 0.57$ & 0.317 \\
\hline F0 & $30.3 \pm 0.57$ & $28.0 \pm 1.73$ & 0.083 \\
\hline F1 & $27.0 \pm 1.73$ & $29.7 \pm 0.57$ & 0.102 \\
\hline F2 & $28.3 \pm 0.57$ & $29.7 \pm 0.57$ & 0.109 \\
\hline F3 & $27.7 \pm 0.57$ & Chi square $=7.607, \mathrm{p}=.055, \mathrm{df}=3$ & \\
\hline KW test & Chi square $=8.23, \mathrm{p}=.041, \mathrm{df}=3$ & & \\
\hline
\end{tabular}

(a.Wilcoxon signed rank test; KW: Kruskall Wallis)

Furthermore, we evaluated the changes of volunteer skin ll moisture increased following increasing concentration ie F1: moisture by calculating the percentage increase as shown in 3.7\%; F2:4.7\% and F3: 7.3\%. The highest improvement was Fig.1. The results showed that the percentage of skin found in F3.

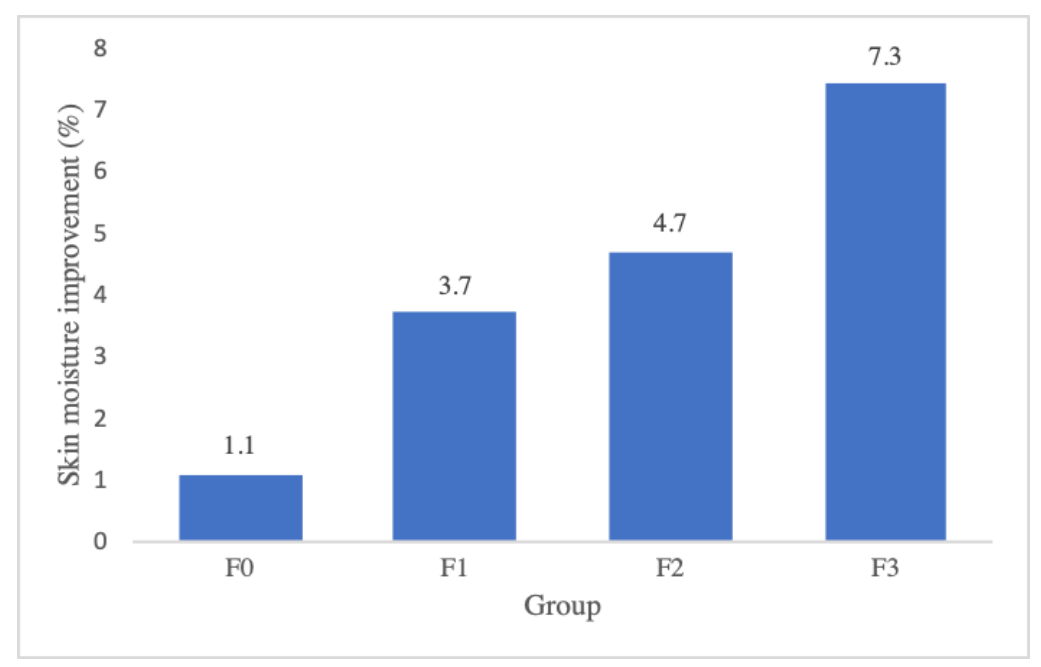

Figure1. Skin moisture improvement after clay mask contained EEAh administration 


\section{Effect of clay mask containing EEAh on pores size}

The effect of EEAh in clay mask formulation on pores size can be seen at Table 2 and Fig.2. Table 2 showed that the pores sizes of volunteer were categorized as large and very large. Thus, after application of mask, they decreased. F1 decreased pores size from $53.0 \pm 6.08$ to $49.7 \pm 5.77 ; \mathrm{F} 2$ from $47,7 \pm 1.52$ to $41.3 \pm 5.03$ and $\mathrm{F} 3$ from $36.0 \pm 3.60$ to $34.7 \pm 3.78$. There were significant different in pores size among groups after clay mask treatment. Significant different was found in F0-F2 $(p=0,046)$ and F0-F3 ( $p=0.046)$.

Table 2: Effect of clay mask containing EEAh on pores size

\begin{tabular}{|l|l|l|l|}
\hline \multirow{2}{*}{ Group } & Pores size & After & \multirow{2}{*}{$p^{a}$} \\
\cline { 2 - 4 } & Before & $49.7 \pm 0.57$ & 0,18 \\
\hline F0 & $51.0 \pm 2.00$ & $49.7 \pm 5.77$ & 0,102 \\
\hline F1 & $53.0 \pm 6.08$ & $41.3 \pm 5.03$ & 0,109 \\
\hline F2 & $47,7 \pm 1.52$ & $34.7 \pm 3.78$ & 0,102 \\
\hline KW test & $36.0 \pm 3.60$ & Chi square $=8.403, \mathrm{p}=.039, \mathrm{df}=3$ & \\
\hline
\end{tabular}

(a.Wilcoxon signed rank test; KW: Kruskall Wallis)

As seen in Fig 2, the higher concentration of EEAh enhanced the pores size reduction. The highest effect was found in F2 $(13.4 \%)$.

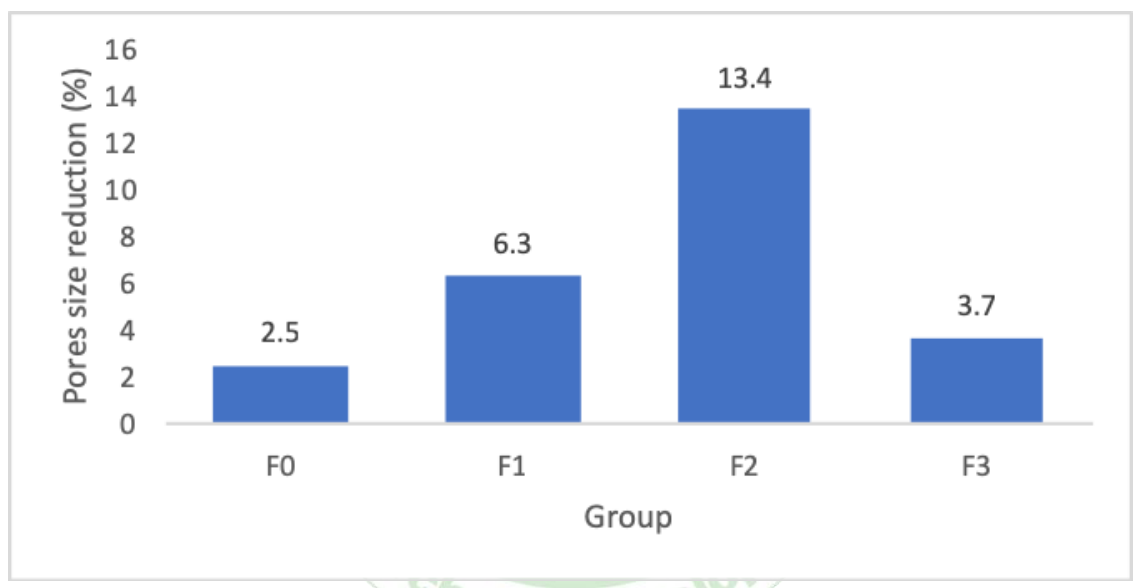

Figure 2. Pores size improvement after clay mask contained EEAh administration

\section{DISCUSSION}

Facial masks are the most prevalent cosmetic products utilized for skin rejuvenation ${ }^{2}$. They may function as carriers of active ingredients that are useful for skin health ${ }^{8}$. The active ingredient activity that believed to posses as skin care is an antioxidant. It is known that natural antioxidants obtained from plants have been developed to decrease the damaging effects in the body ${ }^{9}$. Thus, pharmacological investigations have been conducted on A. heterrophyllus, including as anti-inflammatory ${ }^{10}$, antifungal ${ }^{11}$, antibacterial ${ }^{12}$, and antioxidant ${ }^{13-14}$. These activities could be benefit for skin care.

Clay facial masks have become of special interest due to specific properties presented by clays ${ }^{15}$, At the present study, the selection of base components based on stability and compatibility with ethanol extract of A. heterrophyllus leaves. The basic components consist of bentonite, xantham gum, kaolin, glserin, sodium lauril sulfat, $\mathrm{TiO} 2$, nipagin, natrium metabisulfite and aquadest. The amount of each component was determined based on Harry, 2000 with modification ${ }^{16}$.
The present study showed that before mask application, the volunteer facial skin was in the dehydration-normal skin level (27-30\%). After using clay mask, it became normal (29-30\%). As we know, that the skin needs fat and water for physiological functions, one of which is skin moisture ${ }^{17}$, Skin moisture is a condition that is affected by various endogenous and exogenous factors ${ }^{18}$. If the level of skin moisture is low or the water level is inadequate, it can cause dry skin ${ }^{19}$.Three concentration of the masks in this study showed their ability to increase the skin moisture. This condition suggests that the extract has potency to improve skin hydration. Furthermore, it will be beneficial for facial skin health.

One of the most common skin health problems is aging. This condition can be identified by the enlargement of pores size. Skin pores become enlarged as a result of accumulation of dead skin cells ${ }^{20}$. The present study showed that F1 (1\%) and F2 (3\%) were able to reduce the pores size. It indicated that the ingredient in the clay mask of this study, EEAh, has potency for preventing aging process. 


\section{CONCLUSION}

A.heterophyllus leaf ethanol extract improve skin moisture and pores size, therefore it has potency to be used as facial skin care.

\section{REFERENCES}

1. Luthfiyana N, Nurhikma N, Hidayat, T. Characteristics of peel off gel mask from seaweed (Eucheuma cottonii) porridge. Jurnal. Pengolahan Hasil Perikanan Indonesia,2009; 22(1) 119-127.

2. Nilforoushzadeh MA, Amirkhani MA, Zarrintaj P, Salehi Moghaddam A, Mehrabi T, Alavi S, Mollapour SM. Skin care and rejuvenation by cosmeceutical facial mask. Journal of Cosmetic Dermatology,2018; 17(5) 693-702.

3. Fowler JJ, Woolery-Lloyd H, Waldorf H, Saini R. Innovations in natural ingredients and their use in skin care. Journal of Drugs in Dermatology, 2010; 9 (6 Suppl) S72-81.

4. Heyne K. Tumbuhan Berguna Indonesia Jilid II, Badan Litbang Kehutanan, Jakarta, 1987.

5. Baliga MS, Shivashankara AR, Haniadka R, Dsouza J, Bhat HP. Phytochemistry, nutritional and pharmacological properties of Artocarpus heterophyllus Lam (jackfruit): A review. Food Research International, 2011; 44(7) 1800-1811.

6. Siti. Perawatan tubuh alami ala putri Bali. Accessed from https://tipsperawatancantik.com,2016.

7. Siregar AB. Uji Antibakteri dan antioksidan dari ekstrak metanol daun dan kulit batang nangka sebagai campuran masker. Accessed from http://repositori.usu.ac.id;2018.

8. Novita W. Buku pintar merawat kecantikan dirumah-Kumpulan tips praktis dan murah merawat kecantikan dari ujung rambut hingga ujung kaki. Jakarta: PT. Gramedia Pustaka,2009.

9. Bernatoniene J, Masteikova R, Davalgiene J, Peciura R, Gauryliene R, Bernatoniene R, Muselik J. Topical application of Calendula officinalis (L.): Formulation and evaluation of hydrophilic cream with antioxidant activity. Journal of Medicinal Plants Research, 2011;5(6), 868-877.

10. Fang SC, Hsu CL, Yen GC. Anti-inflammatory effects of phenolic

\section{ACKNOWLEDGEMENT}

This study is supported by USU Grant (Kontrak Penelitian Talenta USU Tahun Anggaran 2019 No. 4167/UN5.1.R/PPM/2019 tanggal 1 April 2019).

compounds isolated from the fruits of Artocarpus heterophyllus. Journal of Agriculture and Food Chemistry,2008; 56(12) 4463-4468.

11. Trindade MB, Lopes JL, Soares Costa A, Monteiro Moreira AC, Moreira RA, Oliva ML, Beltramini LM. Structural characterization of novel chitin-binding lectins from the genus Artocarpus and their antifungal activity. Biochimica et Biophysica Acta (BBA)-Proteins and Proteomics, 2006 1764(1) 146-152.

12. Khan MR, Omoloso, Kihara M. Antibacterial activity of Artocarpus heterophyllus. Fitoterapia,2003; 74(5):501-505.

13. Ko FN, Cheng ZJ, Lin CN, Teng CM. Scavenger and antioxidant properties of prenylflavones isolated from Artocarpus heterophyllus. Free Radical Biology \& Medicine, 1998; 25(2):160-168.

14. Irfan YP. Aktivitas antioksidan ekstrak etanol daun nangka (Artocarpus heterophyllus Lam.) dan penetapan kadar flavonoid totalnya (Doctoral dissertation, Universitas Wahid Hasyim Semarang).

15. Zague V, De Almeida SD, Rolim BA. Mary KT, Valéria RVM. Clay facial masks: Physicochemical stability at different storage temperatures. International Journal of Cosmetic Science, 2007; 29(6):488-489.

16. Harry RG. Harry's Cosmeticology. $8^{\text {th }}$ Ed. New York: Chemical Publishing Co. Inc.,2000; 471-483.

17. Tranggono RI, Latifah F. Buku Pegangan Ilmu Pengetahuan Kosmetik. Jakarta: PT Gramedia Pustaka Utama, 2007; 29-31:107.

18. Tricaesario C, Widayati RI. Efektivitas krim almond oil $4 \%$ terhadap tingkat Kelembapan kulit. Jurnal Kedokteran Diponegoro,2016; 5(4):599-610.

19. Hurlow J, Bliss DZ. Dry skin in older adults. Geriatric Nursing, 2011;32(4):257-262.

20. Noormindhawati L. Jurus Ampuh Melawan Penuaan Dini. Jakarta: Kompas Gramedia, 2013; 2(11):24, 84. 